\title{
Teacher's Practices in Fostering Learner Autonomy in a Thai University Context
}

\author{
Chatrawee Intraboonsom \\ School of Liberal Arts, King Mongkut's University of Technology Thonburi, Bangkok, Thailand \\ Pornapit Darasawang \\ School of Liberal Arts, King Mongkut's University of Technology Thonburi, Bangkok, Thailand \\ Hayo Reinders \\ School of Liberal Arts, King Mongkut's University of Technology Thonburi, Bangkok, Thailand
}

\begin{abstract}
Despite the widespread interest in autonomy and its inclusion in many teacher education programmes, if and how teachers foster autonomy in the classroom is not well-known (Nasri et al., 2015). Especially, in-depth studies of teachers' practices and the factors that influence these are thin on the ground. For this reason, this study was conducted to investigate four teachers' practices, drawing on classroom observations, semi-structured interviews, and a focus group interview, to identify how they fostered learner autonomy and the variables which affected their classroom practices. It was found that the teachers placed greater emphasis on certain dimensions of autonomy, specifically favouring the psychological and technical dimensions over the political and socio-cultural ones. The teachers' decisions to foster learner autonomy were influenced by contextual factors, such as students' language proficiency levels, as well as teacher-internal factors, such as their beliefs about fostering learner autonomy and their own prior learning experiences. We draw from this a number of pedagogical implications for how learner autonomy may be fostered in the language classroom.
\end{abstract}

Index Terms - learner autonomy, teaching practices, teacher's beliefs, Thai university context

\section{INTRODUCTION}

Learner autonomy has been a popular topic in language research and practice for many years. One line of inquiry has been the influence that teachers have on fostering autonomy. Language advising, self-access learning, peer-teaching, peer-assessment, portfolios, reflection, reflective teaching, and digital learning are some of the tools and techniques that have been shown to have an effect (Dam, 2011; Lázaro \& Reinders, 2011). They share a focus on improving the capacity of learners to learn on their own. However, many studies report challenges on the part of both teachers and learners. One factor is that teachers lack the confidence and the ability to foster learner autonomy. Teachers are not sufficiently trained to support autonomous learning (Reinders \& Balçikanli, 2011). Another factor is learners' lack of experience and skills in diagnosing their own learning needs, formulating their own goals, identifying suitable resources, using effective strategies, and monitoring and evaluating their learning. Learners need a significant amount of preparation and ongoing support which many teachers struggle to provide and are not adequately trained for.

In Thailand in particular, there is a need to help students become autonomous learners as Thai students are generally "passive, obedient, uncritical" (Sanprasert, 2010, p. 110). Rungwaraphong (2012) pointed out that Thai students view teachers' role as a knowledge transmitter and teller. Students often wait for directions from the teacher and repeat what the teacher says. Another reason is that the classroom is usually led by the teacher, focusing on grammar-translation methods and assessments (Vibulphol, 2004). These classroom situations do not seem to promote autonomous learning as the support of students' knowledge, skills and strategies for managing their own learning are absent (Darasawang \& Watson Todd, 2012). In fact, previous studies have shown that Thai English teachers have faced difficulties in attempting to develop learner autonomy in their classrooms. Although the concept of autonomy has been perceived as being important among Thai teachers, they are uncertain about how to implement this concept into their teaching practice (Nonkukhetkhong, Baldauf Jr, \& Moni, 2006). Moreover, teachers stick to the teaching methods they are familiar with whereby the teachers are in charge of making decisions concerning what and how to be taught in classrooms, so they are reluctant to change their roles (Punthumasen, 2007). School curriculum and examinations might be another reason which makes it difficult for teachers to implement methods that they think can be beneficial for their students (Tayjasanant \& Suraratdecha, 2016).

When implementing the concept of learner autonomy in the classroom, the teacher and student roles need to be changed. The teachers are expected to be facilitators who create a learning environment in which students can take control of their learning. The students are expected to play active roles to acquire and make decisions for their own learning. Previous studies conducted in Thailand reveal that a teacher can encourage their students to become 
autonomous by, for example, developing the learning skills they might need in order to take control of their learning (Na Chiangmai, 2016), or giving students freedom to make decisions for their learning (Tapinta, 2016). However, the roles and responsibilities of teachers are not limited only to their classrooms. Teachers have to deal not only with students in class but also with curriculum planning and with testing and evaluation. If the teachers have the power to make such decisions, then they can teach or manage the classes in accordance with what they believe is best for their students. Students' level of autonomy then depends on the control of power which teachers transfer to their students. Unfortunately, especially in the Thai context, teachers work in an environment where they may have control over one aspect such as classroom management but may not be able to control other aspects such as curriculum planning, testing and evaluation. Therefore, these factors may be constraints when they try to develop learner autonomy. Given the need to develop learner autonomy, not much is known, especially in the Thai university context, about how teachers attempt to develop learner autonomy in the classroom and what influences that practice. Therefore, this study was conducted to fill this gap in the literature.

\section{LITERATURE REVIEW}

In many countries and contexts, one of the key stated objectives of foreign language programmes these days is to develop learner autonomy, or learners' "capacity to take control of one's own learning" (Benson, 2011, p. 58). This capacity involves the ability to make decisions concerning their own learning goals, what to do and how to achieve those goals, how to monitor the effectiveness of their own learning process and how to assess what they have learned.

To develop learner autonomy, students are not simply allowed to decide whatever they want to do. Learner autonomy in a language classroom encompasses the entire range of giving students' sense of ownership of their learning, equipping them with learning strategies they might need in order to carry out their learning effectively, as well as providing them opportunities to make choices and decisions concerning their own learning. In other words, Littlewood (1996) points out that the process of learner autonomy development needs to include two components, namely ability (i.e., knowledge and skills for learning) and willingness (i.e., motivation and confidence). A teacher may, for example, teach knowledge to learners on how to learn a language which includes providing them learning strategies they might need and also, boosting their confidence in using the language and their own ability to learn. Besides these two components, Dam (2011) highlights that a teacher should involve learners and encourage them to take an active role in the learning process by providing them with choices. The shifting control from a teacher's hand to learners' helps increase learners' motivation to learn and raise their awareness of learning.

A number of studies have been conducted to investigate teachers' beliefs about learner autonomy and their teaching practices to engage learners in the above. Previous research has shown that teachers generally had positive attitudes towards learner autonomy and usually put it in their teaching practices (Borg \& Al-Busaidi, 2012), whilst in practice, they fostered learner autonomy in classrooms by letting students encouraging independent work and giving students responsibility (Borg \& Alshumaimeri, 2019), engaging students in task-based activities (Keuk \& Heng, 2016), developing students' learning strategies (Yang, 1998).

Specifically, in the Thai context, studies which focus on teachers have centred on the teachers' views and beliefs of learner autonomy and how the teachers should encourage autonomy in class and/or their actual practices. For example, Duong and Seepho (2014) employed an open-ended questionnaire and semi-structured interviews to investigate Thai EFL university teachers' perceptions of learner autonomy and their practices in fostering learner autonomy. The majority of the participants identified three roles of the teacher: a facilitator, a counsellor and a resource. In their practice, the teachers reported that they had fostered learner autonomy by asking students to reflect or evaluate their learning progress, allowing them to choose topics, materials, and learning strategies, as well as encouraging them to work outside of the classroom and to use self-access learning centres. However, the teachers faced three major constraints, among others, namely time limitations, students' characteristics as passive and unmotivated learners, and students' ability to make decisions for their learning.

Na Chiangmai (2016) investigated teachers' beliefs about autonomy and the teaching practices they implemented to foster learner autonomy in Thai classrooms. The data was gathered through a questionnaire, interviews, and classroom observations from nine teachers. The findings showed that the teachers believed learner autonomy meant independence from teachers, and they developed learner autonomy by helping their students acquire the learning skills they need and by using self-access learning activities/tasks to make students practice autonomous learning skills. The teachers reported curriculum as a major constraint. They were required to follow the highly prescriptive curriculum which might leave little to no room for the students to make decisions for their own learning.

Another study was conducted by Tapinta (2016). This study was carried out to investigate English teachers' beliefs about learner autonomy and their practices in Thai university contexts. She employed a questionnaire, online (written) interviews, and focus group discussion to collect the data. The findings revealed that the teachers had positive attitudes towards learner autonomy and believed major attributes of autonomous learners were psychological and political factors. The teachers reported that they developed learner autonomy by allowing the students to choose the topics for the lessons and letting them choose materials and sources of information to be used. Moreover, the study reported that students' lack of motivation to learn and students' characteristics as dependent learners were two factors that challenged teachers' practice in developing learner autonomy. 
From the previous studies, it can be seen that teachers have employed a variety of practices in helping to develop the students' ability to take responsibility for their learning. Throughout the process of learner autonomy development, teachers have been faced with some difficulties in integrating autonomy in their actual classroom teaching. Although there are quite a few studies that illustrate how learner autonomy can be promoted in the language classrooms, the number of studies that have investigated teacher's actual teaching practices in fostering learner autonomy is still limited (Nasri et al., 2015). To fill this gap, we conducted our study with the following research questions:

1. What are teachers' practices in fostering learner autonomy in the classroom?

2. What are the factors affecting those practices?

\section{Methodology}

This section details the background of the study, participants, data collection instruments, data collection procedures and data analysis.

\section{A. Theoretical Framework}

Aligned with the research questions above, a qualitative approach was employed to take an in-depth look into how learner autonomy was fostered in a Thai classroom context. The fundamental principle of qualitative research is that it "relies more on the views of the participants in the study and less on the direction identified in the literature by the researchers" (Creswell, 2012, p. 17). This type of research is helpful for a study which wants to describe what happens and explain how or why something happened. Therefore, employing qualitative research is an appropriate approach as this study aims to investigate how teachers went about fostering learner autonomy in their classrooms.

To conceptualize the complexities of teaching practices, we drew on a theoretical framework from teacher cognition theory, which is referred to as what teachers think, know and believe, as it has made a great impact on how teachers implement their practices (Borg, 2003). Several researchers support the notion that teachers' instructional practices depend on what they bring to the classroom (Al-Asmari, 2013), and their beliefs have more impact than their knowledge on how they make decisions for their teaching (Pajares, 1992). Therefore, the study of teachers' beliefs about learner autonomy, especially in a specific context like Thailand, is important as these beliefs can explain what shapes their practices and what informs difficulties in attempting to develop learner autonomy. These understandings can help both teachers and educators have a clearer view on how to help students acquire the skills they need for autonomous learning.

To understand the extent to which teachers implement their beliefs about learner autonomy in their practices, the aspects of autonomous learners should be taken into consideration. According to the literature, learner autonomy is referred to as learners' capacity and ability to make decisions concerning learners' own learning goals, what to do and how to achieve those goals, how to monitor the effectiveness of their own learning process, and how to assess what they have learned (Benson, 2011), learners' freedom and choices (Dam, 2011), learners' willingness to take control of their own learning (Littlewood, 1996), and learners' ability to develop their autonomy through interaction with others (Murray, 2014). Therefore, learner autonomy has been conceptualized in four aspects: technical, political, psychological, and socio-cultural dimensions (Benson, 1997; Oxford, 2003). These four aspects were used to guide this study. The technical dimension of autonomy is referred to as learners learning strategies and techniques. The political dimension of autonomy is referred to as the freedom and control learners have in order to make decisions for their own learning. The psychological dimension of autonomy includes both learners' desire and willingness to take control of their learning and their metacognitive knowledge which could guide them to use metacognitive strategies effectively. The sociocultural dimension of autonomy is related to the situation in which learners' autonomy is developed through social interactions with teachers or other learners. The description and examples of each dimension are in Table I.

TABLE I

DIMENSIONS OF LEARNER AUTONOMY AND ITS DESCRIPTIONS

\begin{tabular}{ll}
\hline \multicolumn{1}{c}{ Dimension of learner autonomy } & \multicolumn{1}{c}{ Description } \\
$\begin{array}{l}\text { Technical autonomy } \\
\text { Benson, 1997) }\end{array}$ & $\begin{array}{l}\text { Looks at how teachers help students to develop their metacognitive strategies and } \\
\text { cognitive strategies, such as helping them identify their learning objectives and helping } \\
\text { them use learning strategies. }\end{array}$ \\
\hline $\begin{array}{l}\text { Political autonomy } \\
\text { (Benson, 1997) }\end{array}$ & $\begin{array}{l}\text { Refers to the freedom and choices a teacher gives to his/her students to determine aspects } \\
\text { of students' own learning, such as letting them choose learning topics for assignments. }\end{array}$ \\
\hline $\begin{array}{l}\text { Psychological autonomy } \\
\text { (Benson, 1997) }\end{array}$ & $\begin{array}{l}\text { Focuses on raising students' consciousness, willingness and motivation to take control of } \\
\text { their own learning, such as helping them have positive attitudes towards the learning } \\
\text { process and developing their metacognitive knowledge. }\end{array}$ \\
\hline $\begin{array}{l}\text { Socio-cultural autonomy } \\
\text { (Oxford, 2003) }\end{array}$ & $\begin{array}{l}\text { Focuses on situations in which learners might learn through social interactions with their } \\
\text { teacher and/or other learners, such as engaging them in interactions with others. }\end{array}$ \\
\hline
\end{tabular}

\section{B. Context of the Study and Participants}

This study was conducted in four classes offered by the department of language studies in a Thai university in Bangkok, Thailand, in which developing learner autonomy had been integrated into the English curriculum for over twenty years. A self-access learning centre was provided so that students had opportunities to learn, practice and 
explore English outside the classroom. The one class was Academic Writing and the other three were General English. These four classes were chosen by the participants. All four class met once a week for three hours over a period of 15 weeks. There were 23 students in Academic Writing class and 35-42 students in each General English class.

Four teachers of undergraduate English courses voluntarily participated in the study. They were selected on the basis of their high scores on a questionnaire we administered, which was based on the questionnaires from Borg and AlBusaidi (2012), Joshi (2011) and Moomaw (2005). The purpose was to identify teachers who have a strong sense of their own autonomy, well-articulated beliefs about learner autonomy, and who report actively fostering autonomy in the classroom. To protect the identity of the teachers, pseudonyms were used. Table II below shows background information of the four teachers.

\begin{tabular}{|c|c|c|c|c|c|}
\hline \multicolumn{6}{|c|}{$\begin{array}{c}\text { TABLE II } \\
\text { PARTICIPANTS }\end{array}$} \\
\hline Name & Gender & Education & $\begin{array}{l}\text { Years of } \\
\text { experience }\end{array}$ & teaching & $\begin{array}{l}\text { Chosen courses to be } \\
\text { included in this study }\end{array}$ \\
\hline Kawin & Male & Doctorate & 11 & & General English \\
\hline Paradee & Female & Masters & 20 & & General English \\
\hline Saran & Male & Masters & 24 & & General English \\
\hline Danai & Male & Doctorate & 21 & & Academic Writing \\
\hline
\end{tabular}

\section{Data Collection Instruments and Data Collection Procedures}

Three data collection instruments were employed, namely classroom observations, semi-structured interviews, and a focus group interview.

Classroom observations

Classroom observations were undertaken to gain a deeper understanding of the process of learner autonomy development in natural classroom settings. The classroom observations focused on teachers' behaviours attempting to foster learner autonomy, the activities they used and how these activities were carried out. The characteristics and features of learner autonomy drawn from Benson (2011) and Murray (2014) were employed to guide the observations. Teaching behaviours of fostering learner autonomy included, for example, teaching students how to identify their own strengths and weakness, demonstrating how to use learning strategies, or allowing the students to use their preferred learning materials. During the observations, the researcher was seated at the back of the classroom watching and making notes without getting involved in or interrupting the class. Observation field notes were used to record information about classroom procedures and activities, using observational questions (e.g., What activities/tasks are used in the classroom? Are students engaged in planning, setting a goal, or finding their own learning strategies?).

Each teacher was observed three times (90 - 180 minutes) spreading out over the semester at the teacher's convenience. The data from these classroom observations were collected by using observation field notes and audio recordings, which were then transcribed for data analysis.

Semi-structured interviews

Three semi-structured interviews were conducted with each participant within a few days after each classroom observation, in order to understand how (s)he went about fostering their students' autonomy. These interviews focused on what the participants had done in the classrooms about developing learner autonomy, the reasons for their practices, and factors affecting their decisions. The interview questions were generated from the classroom observation episodes in which the participants were evaluated as attempting to foster learner autonomy. Practices which occurred frequently were further probed in order to shed light on the teachers' rationale of and beliefs behind those particular methods (e.g., Why did you carry out this activity in class?). After each question, the interviewer would summarize the data to the participants to ensure their mutual understanding before continuing to the next question. Interviews were conducted in Thai, as preferred by the participants, lasting between 20 and 40 minutes. The interviews were audio-recorded and transcribed for analysis.

A focus group interview

A focus group interview with the four teachers was conducted immediately after the course ended so that the participants could see the whole picture of what happened in the classroom and how they went about fostering learner autonomy in their classroom settings. In the focus group interview, the researcher acted as a moderator, asking guiding questions and leading the discussion. The participants could both share their ideas and feelings about their teaching experiences in the course and draw and build on each other's ideas (Borg, 2001). The theme of the questions guiding the discussion included what they had done to foster learner autonomy in their classes, what could be done to enable their students to work autonomously, what factors affected their teaching practice, and what challenges they faced in developing their students' autonomy. This focus group interview was conducted in Thai, audio-recorded and transcribed for data analysis. The interview lasted 40 minutes.

\section{Data Analysis}

To identify the practices employed by the teachers to foster learner autonomy, the data from classroom observations were coded deductively using the four-dimension framework of autonomy taken from Benson (1997) and Oxford (2003) (see Table I). The observation transcripts and observation field notes were read through several times to identify 
teachers' behaviours which promote learner autonomy, or autonomy-supportive behaviours exhibited by teachers. Teachers' behaviours which reveal that they were fostering learner autonomy were highlighted and coded according to the aspects of learner autonomy that the teachers were developing in their students. These codes were then grouped into categories representing the extent to which the participants implemented the teaching practices in fostering learner autonomy and placed under each of the four dimensions of autonomy. Examples of the behaviours included: suggesting learning strategies (technical autonomy), raising students' awareness of their own competence (psychological autonomy), giving students choices (political autonomy), and encouraging peer interaction (socio-cultural autonomy).

Based on the list of practices derived from the analysis above, emerging themes showed the extent to which teachers foster learner autonomy, such as letting the students choose topics for their assignments, explaining the importance of the knowledge of their own proficiency levels, and describing how to use prediction strategies. Such themes were coded and categorized as What-practice, What+Why-practice, How-practice, and How+Why-practice (see Table III for descriptions). The teachers' behaviours were generally identified as What when they had the keywords such as 'you should', 'you have to', while behaviours identified as Why were mostly found using keywords such as 'because', 'so that you can', 'you will learn'. The How behaviours were typically identified when the teachers were describing or elaborating the process of doing something. These four categories of practices were employed to guide the analysis of classroom observation data to identify the extent of how teachers help the students to acquire the ability for independent learning. Frequency counts were conducted on the occurrences of each type of practices performed by the participants.

TABLE III

TYPES OF PRACTICES IN FOSTERING LEARNER AUTONOMY

\begin{tabular}{ll}
\hline \multicolumn{1}{c}{ Type of practices } & $\begin{array}{c}\text { Description } \\
\text { WHAT }\end{array}$ \\
\hline WHAT + WHY & $\begin{array}{l}\text { Mentioning that something is important and/or lets students practice an autonomous action without } \\
\text { important for the students to do so and what benefit they might gain from doing so. }\end{array}$ \\
\hline HOW & $\begin{array}{l}\text { Explaining or illustrating how to do something. The teacher may give examples or suggestions of how to do } \\
\text { it. }\end{array}$ \\
\hline HOW + WHY & $\begin{array}{l}\text { Explaining or illustrating how to do something. The teacher may give examples or suggestions of how to do } \\
\text { it. Additionally, the teacher also explains why it is important for students to do so or what benefits students } \\
\text { might gain from doing so. }\end{array}$ \\
\hline
\end{tabular}

To identify the factors affecting teachers' decisions to develop learner autonomy, the data from semi-structured interviews and focus group interviews were coded inductively. Such codes were used to triangulate teachers' practices. The transcripts of the semi-structured and focus group interviews were closely read. Words, phrases, or sentences indicating how the teachers made their decisions regarding their teaching behaviours were then identified. Later, these segments of information were coded. Finally, these coded segments were categorized into groups of factors which influence their decision making.

To ensure the reliability of the coding, two applied linguists were invited to identify and label teachers' beliefs and their behaviour regarding how learner autonomy was fostered. The two raters were provided with $20 \%$ of the observation and interview transcripts. They were asked to use the dimensions of learner autonomy and types of practices in fostering learner autonomy as guidelines to interpret and label teachers' behaviours regarding the aspects of autonomy that the teachers were fostering and the extent to which the teachers implemented their teaching practices to foster learner autonomy. The inter-rater reliability was computed at $87 \%$ which indicates that the reliability of the data analysis is satisfied.

\section{FINDINGS}

\section{A. Teachers' Classroom Practices in Fostering Learner Autonomy}

The classroom observation data showed that the participants demonstrated a variety of teaching practices to support all four dimensions of autonomy, notably, the psychological and technical autonomy aspects (see Table IV).

To foster psychological autonomy, the results showed that all teachers agreed to advise their students to work outside class and raise awareness of the purposes of the task and what should be done. The findings on the types of practices include What, What +Why and How +Why. The most frequently employed type practice was telling What students should do. Also, raising students' awareness of the task was taught by all four teachers. Kawin, for example, described the purpose of the task which the students were working on. He asked his students to complete 1000 Vocabulary Word Test and explained how significant it was for the students to understand their proficiency levels. He explained, "the test we are doing now is to measure how many words you know based on the first 1,000 word of the most frequently used 3,000 words ... if you know your level you can read books that are in the same level or a little bit higher than you." This excerpt shows that Kawin both engaged students in How they could learn to understand their language proficiency and provided them the reasons Why they need to know about it.

The classroom observation data show two incidents in which socio-cultural autonomy was taught in Danai's class. He fostered socio-cultural autonomy by both telling students What they should do and Why they should do it. Danai said, 'Don't forget to read your friends' diary. You learn a lot from your friends ... You could, like, see some good 
expressions they use...try to react to your friends' post okay?" He first advised the students on what to do and then explained the benefits the students might receive.

TABLE IV

TEACHERs’ TEACHING PRACTICES IN FOSTERING LEARNER AUTONOMY

\begin{tabular}{|c|c|c|c|c|c|c|}
\hline \multirow{2}{*}{$\begin{array}{l}\text { Dimensions of } \\
\text { autonomy }\end{array}$} & \multirow[t]{2}{*}{ Teaching practices } & \multirow{2}{*}{$\begin{array}{l}\text { Sub-dimension of } \\
\text { autonomy }\end{array}$} & \multicolumn{4}{|c|}{ Types of practices } \\
\hline & & & Kawin & Paradee & Saran & Danai \\
\hline \multirow[t]{4}{*}{ Technical } & $\begin{array}{l}\text { (1) Helping or encouraging students to monitor their } \\
\text { own progress }\end{array}$ & $\begin{array}{l}\text { Metacognitive } \\
\text { strategies }\end{array}$ & & $\begin{array}{l}\circ(2) \\
\square(1)\end{array}$ & $\circ(1)$ & \\
\hline & $\begin{array}{l}\text { (2) Helping students make predictions (e.g. using } \\
\text { context clues, part of speech, subject-verb } \\
\text { agreement, and knowledge of the topic) }\end{array}$ & Cognitive strategies & & $\begin{array}{l}\odot(5) \\
\Delta(4)\end{array}$ & $\boldsymbol{\Delta}(3)$ & \\
\hline & $\begin{array}{l}\text { (3) Suggesting additional learning resources (e.g. } \\
\text { vocabulary lists, websites, dictionaries) }\end{array}$ & Cognitive strategies & & $\Delta(2)$ & & $\bullet(2)$ \\
\hline & $\begin{array}{l}\text { (4) Suggesting students to use remembering } \\
\text { strategies }\end{array}$ & Cognitive strategies & & $\boldsymbol{\Delta}(1)$ & & \\
\hline \multirow[t]{3}{*}{ Political } & $\begin{array}{l}\text { (1) Allowing students to choose topics or negotiate } \\
\text { deadlines for assignments }\end{array}$ & Freedom and choices & $\odot(2)$ & $\odot(2)$ & $\circ(1)$ & $\begin{array}{l}\circ(2) \\
\Delta(1)\end{array}$ \\
\hline & (2) Allowing students to negotiate classroom rules & Empowering students & $\circ(1)$ & & & \\
\hline & $\begin{array}{l}\text { (3) Allowing students to express whether they like } \\
\text { or dislike the class and its activities }\end{array}$ & Empowering students & $\circ(2)$ & & & $\odot(1)$ \\
\hline \multirow[t]{5}{*}{ Psychological } & (1) Encouraging students to work outside class & $\begin{array}{l}\text { Motivation to direct } \\
\text { one's own learning }\end{array}$ & $\odot(3)$ & $\odot(1)$ & $\begin{array}{l}\odot(4) \\
\bullet(1)\end{array}$ & • (3) \\
\hline & $\begin{array}{l}\text { (2) Raising students' awareness of their own } \\
\text { proficiency levels }\end{array}$ & Person knowledge & $>(1)$ & & & \\
\hline & $\begin{array}{l}\text { (3) Raising students awareness of the purpose of a } \\
\text { task and what it requires }\end{array}$ & Task knowledge & $\begin{array}{l}\odot(4) \\
\square(1)\end{array}$ & $\odot(3)$ & $\odot(4)$ & $\odot(1)$ \\
\hline & $\begin{array}{l}\text { (4) Encouraging students to overcome their fear of } \\
\text { making mistakes }\end{array}$ & Affective strategies & & $\square(5)$ & & $\square(2)$ \\
\hline & $\begin{array}{l}\text { (5) Encouraging students to give moral support to } \\
\text { their friends for the work they have done }\end{array}$ & Affective strategies & & & & $\odot(2)$ \\
\hline Socio-cultural & $\begin{array}{l}\text { (1) Encouraging students to read and interact with } \\
\text { friends through their online diary }\end{array}$ & Interaction with peers & & & & $\square(2)$ \\
\hline
\end{tabular}

The above findings illustrate that the four dimensions of autonomy can be translated into practices and then be promoted in language classrooms. Psychological and technical dimensions of autonomy were found to be the two most frequently occurred dimensions which suggests that the teacher participants believed that they were crucial to promoting learner autonomy.

\section{B. Factors Affecting Teachers' Decisions to Foster Learner Autonomy}

The interview data revealed that the factors which influenced the teachers' decisions can be categorized into two main groups: contextual and individual (see Table V).

Contextual factors

Students' background knowledge and their proficiency levels were often cited as the reason why and how the participants conducted their classes to encourage learner autonomy. Paradee explained that with low proficiency students, she tended to focus more on the technical dimension by encouraging and helping her students to use metacognitive and cognitive strategies. Paradee said, "working with low proficiency students, I have to help them acquire the learning strategies so that they can develop those skills, and later they can pick and choose those strategies to help them learn by themselves". Another example was in Danai's class. He, at first, allowed his students freedom to choose any topic that they wanted to write about. However, he later decided to limit to three given choices as he recognized that the students had difficulty choosing a suitable topic. He explained, "Thai students expect teachers to spoon-feed them bit by bit. Sometimes when they have freedom to choose whatever they want to do, they are not ready to make a reasonable choice as they have low proficiency levels". 
TABLE V

FACTORS AFFECTING TEACHERS’ DECISIONS TO FOSTER LEARNER AUTONOMY

\begin{tabular}{ll}
\hline \multicolumn{1}{c}{ Factor } & \multicolumn{1}{c}{ Specific code } \\
\hline Contextual factor & Students' background knowledge and their proficiency levels \\
\hline & Students' willingness to learn \\
\hline Teacher's individual factor & School context \\
\hline & $\begin{array}{l}\text { Teacher's beliefs and knowledge about what autonomous learning is and how learner } \\
\text { autonomy should be fostered }\end{array}$ \\
\hline
\end{tabular}

Students' (un)willingness to participate in the classroom was another factor that the participants were concerned with. Kawin, for example, explained, "I have to think about my students' feelings and be willing to learn, too. If they just come to class because they have to, it's quite challenging for teachers to help them become aware that learning is their own responsibility". This helps explain why he allowed his students to express whether they liked or disliked the classroom activities. He wanted his students to get involved in designing their own classroom.

Lastly, the school context which includes school curriculum, final exams, and course books also influenced the teaching practices. The participants agreed that the curriculum directly affected how they decided to foster learner autonomy in their classrooms. Saran said, "Developing autonomy depends on the course. If teachers need to cover a lot of core content with no room for students to practice autonomous behaviours, it would be difficult for them to become autonomous". Moreover, final examinations and course books were factors which impeded the development of learner autonomy. Paradee admitted that she had to follow the course books due to the restriction on the exam. Paradee mentioned, "I have to strictly follow the language expressions or the contents described in the course book. The students have to use them in the exam. I cannot do much to develop learner autonomy in my class." Even though the strict guidelines of what to be taught in the classroom might help to ensure standard across all classes of the same course, some teachers may feel pressured to teach to the test.

Teacher's individual factors

The interview data shows that there was a link between the participants' beliefs and their teaching practices. Kawin expressed his strong belief that to foster learner autonomy in the classroom, students should be provided with freedom and choices. He underscored, "When we let students do as they prefer, we might see that they may have different backgrounds. We can see how different they are, so that we can adjust our teaching accordingly." This helps explain why he offered his students choices on assignments and classroom management to motivate the students.

In addition to freedom and choices, the participants believed that students should be trained to learn by themselves. For Paradee, to develop learner autonomy, she believed students' metacognitive and cognitive strategies were necessary in order to be able to manage their learning effectively. Paradee referred to an autonomous learner as, "someone who knows how and where to start learning ... has to know the process and steps of how to manage his own learning, being able to plan and evaluate his own learning". It can be seen that Paradee consistently encouraged and helped her students to use a variety of metacognitive and cognitive strategies in her class.

The teachers' beliefs not only influenced their classroom practices, but their knowledge about learner autonomy also affected their practices. Kawin emphasized that teachers' knowledge about the SALC is essential. Kawin described, "Teachers should be offered training, they must know the centre and what it can offer, and then they can pass that onto their students". Not being knowledgeable about the SALC, teachers may not be able to utilize the centre to its full benefits.

Furthermore, teachers' belief about teaching and learning language in a class was another factor which had an impact on teachers' practices. Saran was often seen suggesting and demonstrating to his students how to use a predicting strategy which might help the students complete their tasks successfully. In the interview, he explained, "This might help them when they are working on other tasks or even other subjects. They will complete the task faster and more effectively."

Another individual factor affecting teachers' decisions on their teaching practices was teachers' perceptions of their own autonomy. This was seen when Kawin admitted that teacher autonomy had a strong relationship with learner autonomy regarding the political dimension of learner autonomy. He stated, "If the teacher has his own autonomy, the teacher must know how to manage his own teaching. In return, he can guide his students to manage their learning, too". As it can be seen from Kawin' view, teachers who are autonomous learners themselves are aware of the process of learning by themselves, so they might be a better teacher who fosters learner autonomy than those who were not autonomous learners.

\section{DISCUSSION}

Data from classroom observations and interviews with the participants showed that they employed various teaching practices to foster learner autonomy in their classrooms covering all four dimensions of learner autonomy: psychological, technical, political, and socio-cultural. All four participants seemed to focus more on developing psychological dimension, especially the sub-dimensions "motivation to direct one's own learning" and "task knowledge". This is in line with Borg and Al-Busaidi's (2012) and Tapinta's studies (2016) which found that teachers believed that the psychological dimension of autonomy is the strongest indicator of an autonomous learner. This implies 
that the teachers believe that the psychological readiness and being motivated to learn are the two pre-cursors to learners becoming autonomous learners.

In order to help students to be ready to become autonomous learners, the study showed that the students were encouraged to direct their own learning by practicing what they learned outside the classroom. Assuming that these teachers are successful language learners, they all agree that a main part of learning a language takes place outside of the classroom. Therefore, to foster psychological autonomy, the teachers may raise students' awareness of their role as life-long learners by telling students to practice what they have learned outside the classroom

Knowing how to learn was another aspect the teacher participants considered important. The technical dimension of autonomy was fostered in the classroom as the teachers believed that students could autonomously perform better if provided with adequate learning strategies and learning tools. The teachers suggested their students to learn to use quite a few learning strategies, including both metacognitive and cognitive strategies. By letting the students practice using these strategies in class, they may realize and recognize the usefulness of those strategies. In this case, the learners were not only trained on how to learn, but were made aware of their role as the person responsible for their own learning.

With regards to the political dimension, freedom and choices sub-dimension was found in all four participants' classes. The participants gave their students choices on classroom tasks or assignments, classroom activities, and classroom management. These methods could raise students' sense of agency and sense of responsibility for their learning. The participants believed that one of the most important attributes of autonomy is a freedom to make decisions concerning the teaching and learning process. However, giving students choices may not be appropriate when students had limited language proficiency, as in Danai's case. For this reason, the teachers' beliefs about developing the political dimension of learner autonomy could be considered premature in the classroom in which students are reluctant to participate in decision making.

Instances of fostering the socio-cultural dimension of learner autonomy were also found in the classroom observations. They were achieved by encouraging students' interaction with friends (interact with peers sub-dimension) through an online platform so that they could learn from one another. The students can also gain valuable experience through their virtual interaction, in terms of both content and language. Therefore, fostering students to work together is viewed positively since it could encourage students to develop their language and learning abilities through interaction with their peers.

The courses that teachers teach could dictate their decision to foster a certain dimension of autonomy. For instance, in Danai' writing course, he preferred psychological dimension to other dimensions. In a writing class, the nature of teaching writing is very complex in itself, so teachers need to encourage students to take risks and be creative when composing. Therefore, by encouraging the students to use the language without fear of making mistakes, students can become more confident and are not afraid to take risks in language learning and using.

Moreover, from the results, it can be seen that the common challenges faced by teachers in this current study were similar to those found in previous studies. First, students' unwillingness to cooperate with teachers in making decisions for their own learning was found as prominent problem when teachers tried to foster autonomy in the class as occurred in Duong and Seepho's study in 2014. Moreover, curriculum was another vital challenge for teachers in this study which is similar to what $\mathrm{Na}$ Chiangmai (2016) has found. It becomes noticeable that language teachers in Thailand have faced similar challenges in contextual factors which can impede the development of learner autonomy.

Next, findings relating to the types of teachers' teaching practice will be discussed. To encourage learner autonomy, the teachers generally suggested What should be done or get students involved in activities in which they have to perform such practice. However, teachers may need to go beyond What should be done as the 'What' might not give students enough momentum or reason for students to experiment and later adopt the suggested practice. The integration of explaining How to do it and Why they should do it may have a greater effect on the students. By giving a student reason to adopt a new practice, it enables students to start an internalization process (Reeve, Jang, Hardre, \& Omura, 2002).

Therefore, to foster meaningful learner autonomy, teachers should be aware of not only the dimensions of autonomy but also the types of practice as well. Suggestions (What), demonstrations (How), explanations (Why) are also found to be an integral part in teachers effectively promoting learner autonomy in a classroom setting. The key in fostering autonomy may lie in teachers being prepared to ensure that each of their classroom instructions encompasses all these three types of practice.

\section{CONCLUSIONS AND PEDAGOGICAL IMPLiCATIONS}

This study demonstrates the extent to which these Thai English language teachers fostered learner autonomy in their teaching practice. Classroom observations provided an insight into a wide range of practices that the teachers employed to encourage learner autonomy in their classroom. These included developing students' metacognitive knowledge, suggesting metacognitive strategies and cognitive strategies, and giving them choices over their learning. Teachers, as a result, play an important role in the classroom when it comes to providing students opportunities to develop their autonomy. This study shows that it is possible to encourage learner autonomy, especially in a context where the teachers are expected to be in control, by both creating an environment where the students can practice control over aspects of their own learning and by preparing them to be able to make effective choices. 
This paper introduces the 'types of practices', i.e., What, What+Why, How, and How+Why as an analytical framework to describe teachers' actions in greater detail in order to give insights on how teachers foster learner autonomy. We have demonstrated that the use of 'types of practices' is possible and could be used to complement the four dimensions of autonomy advocated by Benson (1997) and Oxford (2003). Future research may explore the effectiveness of teacher actions in fostering learner autonomy by investigating students' insights which help teachers adapt and design activities to support learner autonomy.

This study illustrated the types of practices teachers have at their disposal to encourage learner autonomy in the language classroom. In addition to the frequently used What-type of practice, teachers could go further by showing students How to do it and justifying $($ How + Why) the necessity of doing it. The classification of the types of practices shows the choices that teachers have in promoting learner autonomy. The What-practice would be used more effectively if combined with the How + Why practice to make a strong impression on students for that particular teaching practice by giving them specific instruction, direction, and explanation or justification behind it. For example, to use Whatpractice, teachers may encourage students to practice further what they have learned outside the classroom, mentioning, "You should practice this at home. You can't learn a language in the classroom only." To integrate What+Why-practice, teachers may say, "You should practice this at home. When you learn a language and practice it more in the real world, you will be able to use the language better. The more you practice, the better you will be." To implement How-practice, teachers may suggest websites where students can practice more, saying, "You can use the Oxfordlearn website. ... In the Oxfordlearn.com website you can choose the language skills that you want to improve such as writing or even speaking." To use How + Why-practice, teachers might say, "Although there are quite a few English words, the research identified the most frequently used 3,000 words as the most important. This is because by knowing these 3,000 words, learners can understand 80 percent of the language they encounter. The test we are doing now is to measure how many words you know based on the first 1,000 words of the most frequently used 3,000 words."

Our study was largely qualitative in nature and explored the extent to which teachers attempt to foster autonomy and only observed a small number of classes. In future research, complementing qualitative research with quantitative research as well as recruiting a large number of participants and extending the study time frame could provide a wellrounded and more descriptive pictures of how, what transpires in a language classroom and why.

\section{REFERENCES}

[1] Al-Asmari, A. (2013). Practices and prospects of learner autonomy: Teachers' perception. English Language Teaching 6.3, 110.

[2] Benson, P. (1997). The philosophy and politics of learner autonomy. In P. Benson \& P. Voller (eds.), Autonomy and independence in language learning. London: Longman, 18-34.

[3] Benson, P. (2003). Learner autonomy in the classroom. In D. Nunan (ed.), Practical English language teaching. Singapore: McGraw Hill, 289-308.

[4] Benson, P. (2008). Teachers' and learners' perspectives on autonomy. In T. Lamb, \& H. Reinders, (eds.), Learner and teacher autonomy: Concepts, realities, and responses. Amsterdam: John Benjamins, 15-32.

[5] Benson, P. (2011). Teaching and researching autonomy in language learning (2nd edn.). London: Longman.

[6] Borg, S. (2003). Teacher cognition in language teaching: A review of research on what language teachers think, know, believe, and do. Language Teaching 36.2, 81-109.

[7] Borg, S., \& Al-Busaidi, S. (2012). Teachers' beliefs and practices regarding learner autonomy. ELT Journal 66.3, $283-292$.

[8] Borg, S., \& Alshumaimeri, Y. (2019). Language learner autonomy in a tertiary context: Teachers' beliefs and practices. Language Teaching Research 23.1, 9-38.

[9] Creswell, J. W. (2002). Educational research: Planning, conducting, and evaluating quantitative. Upper Saddle River, NJ: Prentice-Hall.

[10] Dam, L. (2011). Developing learner autonomy with school kids: Principles, practices, results. In D. Gardner (ed.), Fostering autonomy in language learning. Gaziantep: Zirve University, 40-51.

[11] Darasawang, P., \& Watson Todd, R. (2012). The effect of policy on English language teaching at secondary schools in Thailand. In L. Ee-Ling \& A. Hashim (eds.), English in Southeast Asia: Features, policy and language in use. Philadelphia, PA: John Benjamins, 207-220.

[12] Duong, T. M., \& Seepho, S. (2014). Promoting learner autonomy: A qualitative study on EFL teachers' perceptions and their teaching practices. Proceedings of the International Conference: DRAL 2 /ILA 2014, 129-137.

[13] Joshi, K. R. (2011). Learner perceptions and teacher beliefs about learner autonomy in Language learning. Journal of NELTA $16.1,13-29$.

[14] Lázaro, N., \& Reinders, H. (2011). Language learning and teaching in the self-access centre: A practical guide for teachers. Sydney, Australia: NCELTR.

[15] Littlewood, W. (1996). Autonomy: An anatomy and a framework. System 24.4, 427-435.

[16] Maxwell, J. A. (2013). Qualitative research design: An interactive approach. Los Angeles: SAGE.

[17] Moomaw, W. E. (2005). Teacher-perceived autonomy: A construct validation of the teacher autonomy scale (Unpublished doctoral dissertation). University of West Florida, Florida, United States.

[18] Murray, G. (2014). Exploring the social dimensions of autonomy in language learning. In G. Murray (ed.), Social dimensions of autonomy in language learning. London: Palgrave Macmillan, 3-11.

[19] Na Chiangmai, S. (2016). Autonomy in Thai universities: English teachers' beliefs and practices (Unpublished doctoral dissertation). University of New South Wales, Sydney, Australia. 
[20] Nasri, N., Eslami Rasekh, A., Vahid Dastjerdy, H., \& Amirian, Z. (2015). Promoting learner autonomy in an Iranian EFL high school context: Teachers' practices and constraints in focus. International Journal of Research Studies in Language Learning 4.3, 91-105.

[21] Nonkukhetkhong, K., Baldauf Jr, R. B., \& Moni, K. (2006). Learner centeredness in teaching English as a foreign language: Teachers' voices. Paper presented at 26 Thai TESOL International Conference, Chiangmai, Thailand, 19-21 January 2006, 1-9.

[22] Oxford, R. L. (2003). Toward a more systematic model of L2 learner autonomy. In D. Palfreyman \& R. C. Smith (Eds.), Learner autonomy across cultures. New York: Palgrave Macmillan, 75-91.

[23] Pajares, M.F. (1992). Teachers' beliefs and educational research: Clearing up a messy construct. Review of Educational Research 62.4, 307-331.

[24] Punthumasen, P. (2008). International program for teacher education: An approach to tackling problems of English education in Thailand. Paper presented at The 11th UNESCO-APEID International Conference Reinventing Higher Education: Toward Participatory and Sustainable Development, 12-14 December, Bangkok. Retrieved from http://backoffice.onec.go.th/uploaded/Category/EngBook/ProblemEngEd13dec07-03-03-2011.pdf.

[25] Reeve, J., Jang, H., Hardre, P., \& Omura, M. (2002). Providing a rationale in an autonomy-supportive way as a strategy to motivate others during an uninteresting activity. Motivation and Emotion 26.3, 183-207.

[26] Reinders, H., \& Balçikanli, C. (2011). Learning to foster autonomy: The role of teacher education materials. SiSAL Journal 2.1, $15-25$.

[27] Rungwaraphong, P. (2012). Student readiness for learner autonomy: Case study at a university in Thailand. Asian Journal on Education and Learning 3.2, 28-40.

[28] Sanprasert, N. (2010). The application of a course management system to enhance autonomy in learning English as a foreign language. System 38.1, 109-123.

[29] Tapinta, P. (2016). Thai teachers' beliefs in developing learner autonomy: L2 education in Thai universities. In R. Barnard (Ed.) Language learner autonomy: Teachers' beliefs and practices in Asian contexts. Phnom Penh, Cambodia: IDP Publications Asia, 96-113.

[30] Tayjasanant, C., \& Suraratdecha, S. (2016). Thai EFL teachers and learners' beliefs and readiness for autonomous learning. $3 L$ : The Southeast Asian Journal of English Language Studies 22.3, 153-169.

[31] Vibulphol, J. (2004). Beliefs about language learning and teaching approaches of pre-service EFL teachers in Thailand (Unpublished doctoral dissertation). Oklahoma State University, Oklahoma, United States.

[32] Yang, N. (1998). Exploring a new role for teachers: Promoting learner autonomy. System 26.1, 127-135.

Chatrawee Intraboonsom, is a $\mathrm{PhD}$ candidate at School of Liberal Arts, King Mongkut's University of Technology Thonburi. She obtained her Master of Arts in Applied Linguistics from Mahidol University. She is currently working on teacher and learner autonomy.

Pornapit Darasawang, $\mathrm{PhD}$, is Vice President for Internationalisation at King Mongkut's University of Technology Thonburi, Thailand and an associate professor in the Department of Languages, School of Liberal Arts. Her areas of interest are learner autonomy, learner training, and motivation in language learning.

Hayo Reinders (http://innovationinteaching.org), $\mathrm{PhD}$, is Professor of Applied Linguistics at King Mongkut's University of Technology Thonburi in Thailand and Professor of Education at Unitec in New Zealand. He has published over 20 books and 100 articles in the areas of autonomy, technology, teacher education and out-of-class learning. 